The creation of the Wildcat Hill ilderness area has been the result of le work of a great many organizaons and individuals. The Regina atural History Society held a series field trips in the Hills the report which appeared in the Blue Jay in 964. The Saskatchewan Natural Hisry Society passed in 1965 the first ficial motion asking for a wilderness rea to be set aside and this was in irn supported by the Saskatchewan Vildlife Federation in 1965 and 1970. Ir. Mazure brought the matter to the ttention of the provincial Homeoming Committee and obtained the upport of the town of Hudson Bay. he sympathetic co-operation of the impson Lumber Company in withrawing its cutting rights also contri- buted in making the proposal possible. Indeed, fishermen, canoeists, naturalists, biologists, as well as many interested private citizens, have all assisted in creating a favourable climate of public opinion. Most important is the foresighted attitude of the Department of Natural Resources without which no progress could have been made.

The fascination of the Pasquia Hills, then, lies in their wild and inaccessible nature and in the knowledge that so many animal and plant species live within them. With the establishing of this first wilderness area all conservationists will experience a sense of pride and a further stimulus to work for the setting aside of other similar areas in the province.

\title{
THE PROPOSED ARCTIC INTERNATIONAL WILDLIFE RANGE
}

\section{by Everett B. Peterson, Vancouver, B.C.}

Members of the Saskatchewan Natral History Society will be interested i following the outcome of the confernce on the Arctic International Wildife Range because in the manner in which it was structured, its goals, and he various follow-up steps this conerence could serve as a model for ringing together the interests of conervationists, industrialists and govrnments and for developing an aproach to land management that all an endorse. While we must await the utcome of proposals from this conerence, it is evident that it represented in important first step toward desigation of an Arctic International Wildlife Range in an area that still ossesses, comparatively unchanged, in unusually wide range of landforms ind native life, including indigenous eople. Of particular importance are he caribou, currently numbering in excess of 100,000 , that have an interhational migration pattern in the area proposed for a Wildlife Range. The habitat of these large herds is still intact but their future cannot be guaranteed without a substantial range that is permanently protected in both the Yukon Territory and Alaska.

The conference was held at Whitehorse, Yukon Territory, on October 21 and 22, 1970; it was hosted by the Yukon Conservation Society and was under the general chairmanship of Dr. A. R. Thompson, Faculty of Law, University of British Columbia. Conference delegates, 50 from Canada and 14 from the United States, included representatives of the native peoples, Federal and Territorial governments, industries, universities, and several conservation organizations. The broad objective of the conference was to explore ways by which the diverse interests in the extreme northern part of the Yukon Territory might be adjusted to allow designation of a wildlife range in Canada that would be continuous with Alaska's Arctic Wildlife Range. 
The conference proceedings will be published in the June issue of the University of British Columbia Law Review and will include the background paper prepared for the conference by Conservation Associates, San Francisco, all resolutions, and the following papers:

Opening address: J. Smith, Commissioner of the Yukon Territory.

History and status of the Arctic National Wildlife Range, J. D. Findlay, Regional Director, U.S. Fish and Wildlife Service, Portland, Oregon. Wildlife resource and its conservation in northern Yukon Territory, A. M. Pearson, Research Scientist, Canadian Widlife Service, Whitehorse, Yukon;

Some economic and social implications of the proposed Arctic International Wildlife Range, P. H. Pearse, Department of Economics, University of British Columbia, Vancouver.

The significance of the proposed wildlife range to industry. E. L. Patton, President, Alyeska Pipeline Service Co.;

A legal structure for the proposed wildlife range. A. R. Thompson, Faculty of Law, University of British Columbia, Vancouver.

Ice Age mammal research in the Yukon Territory and Alaska, C. R. Harington, Curator of Quaternary Zoology, National Museum of Natural Science, Ottawa.

The central resolution of the conference dealt with land use and was worded as follows:

"This conference resolves that the uses which society as a whole may make of the area, including research, interpretation of natural and prehistoric cultural phenomena, wildlife and fisheries management, petroleum and mineral development, pipeline and other transport routes, disposition of surface deposits such as gravel and support of hunting and sport fishing, may be permitted on all or part of the range as will be determined by the management authority, under such restrictions and regulations as are necessary to maintain wildlife populations and safeguard the traditional life of the native peoples."

An interim committee has bee appointed to carry forward the confer ence resolutions and to seek to inte grate the establishment of a wildlif range with the implementation of land use regulations under the Territoria Lands Act (1970). Members of th interim committee are: Ian McTag gart Cowan, Dean, Faculty of Grad uate Studies, University of Britis. Columbia; John Tener, Director Canadian Wildlife Service, Ottawa Michael Stutter, Yukon Territoria Councillor; Bob Cathro, Archer, Cathr and Associates, Consulting Engineer Vancouver; George L. Collins, Conser vation Associates, San Francisco Andrew R. Thompson, Faculty , Law, University of British Columbic

The proposal to establish a wildlif range has been presented to th Minister of Indian Affairs and North ern Development and is now unde study by officers of that Departmen There has been a positive response the suggestion that the initial ste should be designation of the propose wildlife range as a land managemer zone when the land-use regulations ar brought into force. For this to occu there must be a continuation of th kind of support and enthusiasm th: was displayed at the Whitehorse con ference. To this end, a society is beir incorporated under the Yukon Ordi ances. It is visualized that the societ will assist in a research and educatir role for at least a five-year period until an Arctic International Wildli Range and an established manag ment authority become realities. Cha ter members of the society will drawn from amongst those who atten ed the Whitehorse conference. Anyo else wishing to support the objectiv of the proposed society and to becor members-at-large should contact $M$ John Lammers, Box 1063, Whitehor Yukon.

Readers interested in a copy of $t$ complete conference proceedings $\mathrm{m}$ obtain one from Mr. Dennis McCre Faculty of Law, University of Briti Columbia, Vancouver 8, B.C. 